\title{
MACHINE VISION METHOD FOR QUALITY EVALUATION OF COW MEAT
}

\section{H. E. Hassan ${ }^{1}$, A. A. Abd El-Rahman ${ }^{2}$ and F. M. Shehata ${ }^{3}$}

\begin{abstract}
The aim of the present research was to determine physical and chemical properties of different muscles cut of cow meat, studying effect of physical and chemical changes on color properties of meat samples and quality evaluation for cow meat using image processing. Measurements of color properties were carried out at the Laboratory of Laser Application in Agriculture Engineering at National Institute of Laser Enhanced Science (NILES), Egypt. While, the physical and chemical properties of meat samples were analyzed in the Research Park, Faculty of Agriculture, Cairo University, Giza, Egypt. The samples, were abscised from four muscles representing common retail cuts in the local market in Egypt (Round (Leg), Shoulder, Hind shank and Best ribs). Determination of chemical properties of the meat samples (moisture content, protein, fat, ash, $\mathrm{pH}$ and collagen) and physical characteristics (cooking loss, water holding capacity, and shear force) and color properties (intensity, saturation values and hue degree) were measured during season 2008 - 2009.

The obtained results were as following: (a) By increasing of the shear force and the water holding capacity and decreasing the cooking losses of meat sample, these result led to the lowering of intensity and saturation values. While increases of the hue degree for best ribs, shoulder, round and hind shank of meat cut type of cow.,
\end{abstract}

1- Associate Prof., Nat. Inst. of Laser Enhanced Sc. (NILES), Cairo Univ., Egypt.

2- Senior Researcher, Agric. Eng. Res. Institute, Agric. Res. Center, Dokki, Egypt.

3- Postgraduate, Nat. Inst. of Laser Enhanced Sc. (NILES), Cairo Univ., Egypt 
(b) By decreasing the moisture content, fat, and ash percentages and increasing the protein, collagen percents and $\mathrm{pH}$ values led to decrease the intensity and saturation values of meat cut while hue degree was increased for best ribs, shoulder, round and hind shank, respectively., (c) The best ribs sample has high intensity of light, lighter of saturation and red color degree than shoulder, round and hind shank samples. While, the hind shank sample was the lowest of intensity, darker and more red color degree., and (d) Image processing as a machine vision technique can be used for evaluating quality of meat cut types.

\section{INTRODUCTION}

merican Meat Science Association (1991) refers to color methodology there are three major considerations: what instrumental methodology to use (pigment extraction or reflectance), how to express the data and how to use the data. For example, Hunter Lab-values or CIE Lab-values, tristimulus values, Munsell and reflectance at specific wavelengths have all been used to express color data. Ratios of $\mathrm{a} / \mathrm{b}$ colere, hue angle and saturation index have been used for discoloration studies various reflectance values have been used often to measure meat color, to follow color changes.

Li et al. (2001) founded that marbling and color characteristics, and thereby, the final grade, only explain a rather low percentage of the variations in important palatability measures such as tenderness. Measures of beef quality have been a long time desire of the industry and there have been many research efforts in developing instruments. One popular, and obvious, approach has been to measure the mechanical properties as indicators of tenderness.

Denoyelle and Berny (1999) mentioned that the veal industry relies heavily on lean color for carcass grading and determination of carcass value. Ideal lean color is a pale, creamy ink; however, most packers consider a grayish-pink lean color acceptable. Throughout the veal industry, lean color is appraised visually by unit operator.

Lu et al. (2000) founded that not only RGB (red, green, blue) color space, but also HSI (hue, saturation, intensity), HSL (hue, saturation, 
lightness), and HSV (hue, saturation, value) spaces are popular in the quality evaluation of meat.

Sun (2000) referred to the criteria for like-pixels can be based on grey level, color and texture. The segmented image may then be represented as a boundary or a region. Boundary representation is suitable for analysis of size and shape features while region representation is used in the evaluation of image texture and defects.

James (2007) said that the main factors that affect the color include: pigment concentration, chemical state of the pigment, $\mathrm{pH}$, reducing activity, meat respiration rate (oxygen consumption), time, temperature (cooking and storage), packaging system employed and microbial load. Using color as an indicator of adequate cooking in the case of premature browning is not recommended because the product may actually be undercooked.

Hal Good (2007) mentioned that it is easy to understand why color is an important attribute to the food industry. We frequently judge food quality based on color. However food processors are often limited in their ability to adjust color in the final product. Color measurement instruments are used to check ingredient color and to evaluate the efficiency of processes in obtaining or maintaining the desired. Color is used not only in evaluating ingredients, but to evaluate the cooking or baking process and its effect on the final product .

Chance Brooks (2007) said that the meat color is a primary factor affecting consumer purchase decisions and the most favorable meat color is red. Beef can naturally exist in many colors; including red, purple and brown as well as yellow and green. Meat contains the protein myoglobin, which is responsible for meat color and a change in myoglobin results in a change in meat color. The state of the iron and the nature of the components attached to the binding site determine the color of meat.

Abril et al. (2001) mentioned that the color plays a very important part in quality evaluation, as it is one of the main appearance attributes that determine the purchase decisions on meat. Color has been correlated to sensory score, $\mathrm{pH}$ value, storage time and temperature.

Hatem et al. (2003) reported that the color features obtained from RGB (red, green, blue) color space contained the most significant information 
of beef marbling scores and RGB space was not so suitable as the HSL (hue, saturation, lightness) color space for the skeletal maturity grading of beef carcasses since color features from HSL space could be used to determine the maturity grade.

Kayaardi and Gok (2003) referred that there is potential link between beef color and moisture content. The moisture is one of the most important chemical compositions, which makes up about $80 \%$ of the total meat volume Therefore, color and moisture might be related to each other. So the color varied as moisture content changed in different meat products.

Gunasekaran (2001) clearly that the various aspects of illumination including location, lamp type and color quality, need to be considered when designing an illumination system for applications in the food industry. The most lighting arrangements can be grouped as either front or back lighting. Front lighting (electron projection lithography or reflective illumination) is used.

Chandraratne et al. (2006) founded that the marbling and color scores have been used as indicators of beef tenderness. But color and marbling scores have limited power to predict cooked beef tenderness. The possible reason for this poor prediction is that color and marbling scores do not contain reliable information about tenderness.

Dave McKenna (2007) mentioned that the consumers expect beef to be a bright, the cherry-red color, pork a reddish-pink color, and lamb a pinkish-red color. Muscle fibers contain varying amounts of myoglobin, the main muscle protein responsible for color, with beef muscles containing higher concentrations than pork muscles. Most color irregularities are related to the water-holding properties of the muscle. High $\mathrm{pH}$ muscle, such as dark cutting beef or dark, firm, and dry pork. The objectives of this research work was: (a) to determine of physical and chemical properties for different muscles cut of cow meat, (b) to determine of color properties for meat cuts, (c) studying the relationship among color properties and physical and chemical properties of meat samples and (d) using set up of machine vision for quality evaluation for cow meat cuts. 


\section{MATERIAL AND METHODS}

The color properties were carried out at the Laboratory of Laser Application in Agricultural Engineering at National Institute of Laser Enhanced Science (NILES), Cairo University, Egypt and the physical and chemical properties of meat samples were analyzed in the Research Park, Faculty of Agriculture, Cairo University, Giza, Egypt during season 2008- 009.

\section{1-Animal and meat samples:}

Meat samples were obtained from the researching farm of the Faculty of Agriculture, Cairo University, Egypt. It was taken from carcass of male of Egyptian native cattle (Baladi Bullocks). With a live weight of $350 \mathrm{~kg}$ at an average age of two years. It was fed with traditional method (Egyptian feds).

The animal slaughter and dressing followed normal commercial procedures. The samples, were abscised from four muscles representing common retail cuts in the local market in Egypt :( Round (Leg), Shoulder, Hind shank and Best ribs), as shown in Fig. (1). The beef samples were sectioned into smaller slices', and divided into shares with weight (approximately $150-200 \mathrm{~g}$ ). The beef samples were kept in a fridge $\left(4 \pm 8^{\circ} \mathrm{C}\right)$ for 24 Hours in plastic bags before measurements.

2- Chemical analysis, Moisture, protein, fat and collagen, using Food Scan ${ }^{\text {TM }}$ Pro meat analyzer (Foss Analytical A/S, Model 78810, and Denmark). According to the manufacturer's instructions about 50 - 100 gm of raw meat samples' were minced and put in the meat analyzer cup. The cup was inserted into the meat analyzer for scanning sample with infra red to determine the chemical components.

The ash content, was determined by weighted $10 \mathrm{~g}$ of muscle samples into porcelain crucible previously weighted. Samples were heated at $100 \mathrm{C}^{\circ}$ to expel moisture, and then were placed in temperature controlled to $600 \mathrm{C}^{\circ}$, and hold at this temperature for 2 hours. The ash percentage was calculated by the following equation.

$$
\text { Ash \% = (W1-W2)/W1x100 }
$$

Where: $\mathrm{W} 1=$ weight of meat before measuring, $\mathrm{g}$ and

$\mathrm{W} 2=$ weight of meat after measuring, $\mathrm{g}$. 
3-Physical characteristics: physical characteristics such as cooking loss, water holding capacity, shear force, $\mathrm{pH}$, and color were measured.

Water Holding Capacity (\%), was measured which meat sample of about $0.3 \mathrm{~g}$ (W1) was placed on a filter paper and then subjected to a pressure of $1000 \mathrm{~g}$ for 10 minutes. The expressible fluid was estimated using the following equation

Water Holding Capacity \% = (W3-W4)/W3x100

Where: W3= weight before measuring, $g$ and $\mathbf{W} 4=$ =weight after measuring, $g$

Cooking loss (\%), was determined using 2 cubes of meat (about 100 gm, W1). The samples were boiled in saline $(0.09 \% \mathrm{Nacl})$ for 45 minutes, and then were left to be cool at room temperature. Sample was re-weighed (W2) to calculate the cooking loss percentage according to the following equation.

Cooking loss, $(\%)=($ W5-W6 $) / W 5 \times 100$

Where: $\mathbf{W 5}=$ weight before measuring, $g$ and $\mathbf{W 6}=$ weight after measuring, $g$ Shear force (kg), the cooked samples were used for determining the shear force $(\mathrm{kg})$. For estimating shear force using Instron Universal Testing Machine (Model 2519-105, USA). The shear force machine was adjusted at crosshead speed of $200 \mathrm{~mm} / \mathrm{min}$.

pH, was measured using five grams of meat according to the following methodology. Samples were minced, and put in graduated glass beaker, before filling the beaker with distilled water up to $50 \mathrm{ml}$. The mixture (meat and water) was shacked. PH of the obtained suspension was measured by Micro processor $\mathrm{pH}$ meter ( $\mathrm{PH} 211$, Micro processor $\mathrm{pH}$ meter, Hanna instruments, Italy).

\section{Color properties:}

Meat color was measured using Croma meter (Konica Minolta, model CR 410, Japan) as shown in Fig (2). Calibrated with a white plate and light trap supplied by the manufacturer. Color was expressed using the CIE (Commission Internationale de l'Eclairage) $\mathrm{L}$, a, and b color system. A total of three spectral readings were taken for each sample on different locations of the muscle. L (lightness) values measure (higher $\mathrm{L}$ value indicates a white color, while lower L value indicates a black color); a values measure redness (positive a value indicates a reddish color, while negative value measures 


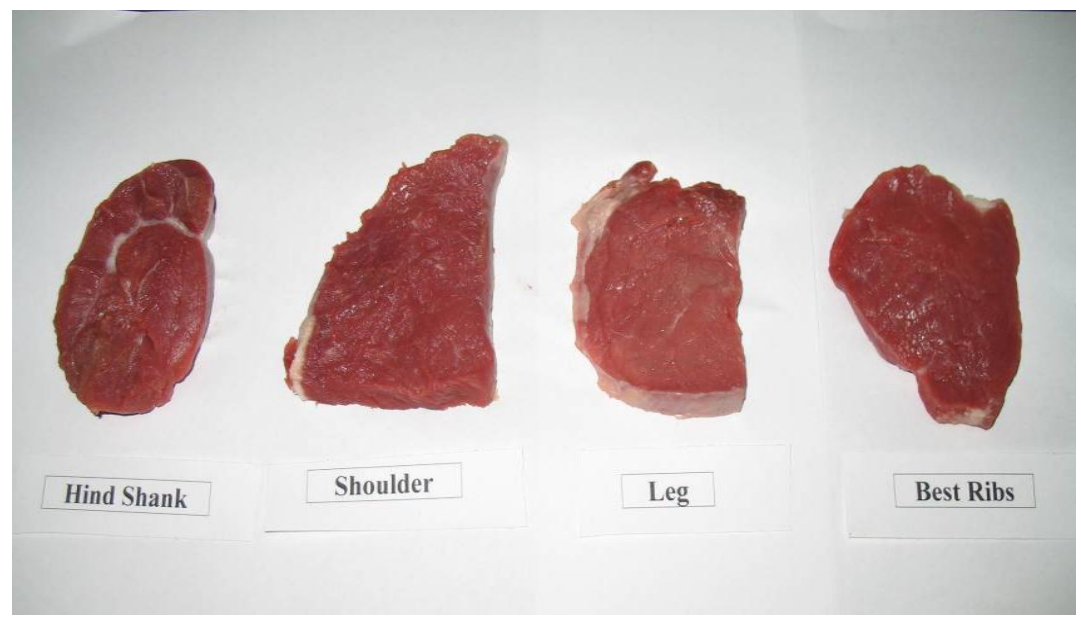

Fig. (1): The meat samples, representing common retail cuts in the local market in Egypt.

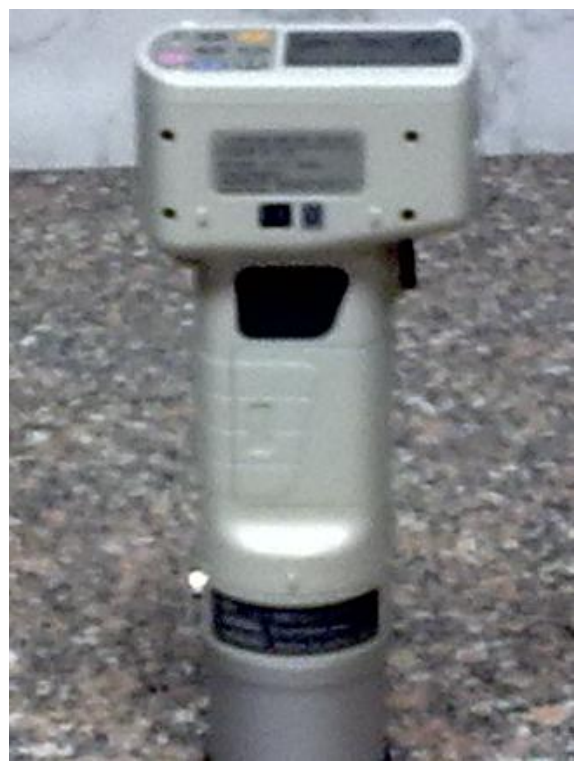

Fig. (2): Croma meter used to measure meat color samples by the CIE L, a, and b color system. 
greenish); and $b$ values measure yellowness (positive $b$ value indicates a more yellowish color, while negative value measures blueish). Higher values of lightness and positive one of redness \& yellowness indicate that color meat was better that lower values of lightness and negative values of redness \& yellowness.

-Hue degree $(\varphi)$.hue angle may be defined as the angle between the hypotenuse and $0 \circ$ on the (blue-green / red -yellow) axis, However, positive values use in the first and third and negative values in the second and fourth the quadrants, according to Balkeniues et al (2003). Hue angle, can be computed from the following equation (4)

$\Phi=\arctan (\mathrm{a} / \mathrm{b})$ or $\Phi=\tan ^{-1}(\mathrm{~b} / \mathrm{a})$

Where: $\varphi$ is the hue angle degree., a: is the (red-green)axis, values, and b: is the 9yellow-blue)axis, values

\section{-Saturation $(\sigma)$ :}

$(\sigma)$ Was referred to color saturation according to Balkenius et al (2003). This can be calculated from the following equation (5) and represents the hypotenuse of a right triangle created by joining points $(0,0),(a, b)$ and $(\mathrm{a}, 0)$

$$
\sigma=\sqrt{(a)^{2}+(b)^{2}--}
$$

Where: $\sigma$ : is the saturation value, a: is the (red-green) axis, values, and $b$ : is the (yellow-blue)axis, values.

\section{RESULTS AND DISCUSSION}

The results are presented and discussed to study possibility of using color analysis to establish measuring of color properties of different muscle cut types of cow meat in order to evaluate quality of meat.

\section{-Effect of physical characterizations on color properties of meat cut types of cow:}

Table (1) and Fig (3) showed that the effect of shear force, cooking loss, and water holding capacity percentage as physical properties on intensity as the color properties of meat cut types of cow. The data referred that the values of the intensity were decreased from 37.91, 37.02, 36.32 and 35.62 for best ribs, shoulder, round and hind shank, respectively. Increases the shear force from 4.82, 5.20, 6.25 and $9.31 \mathrm{~N}$, and the water 
holding capacity from $26.18,29.07,31.43$ and $37.7 \%$ while, the cooking losses percentage were decreased from 51.88, 49.65, 46.44, and $43.66 \%$, for best ribs, shoulder, round and hind shank, respectively. That is mean by increasing of the shear force and the water holding capacity and decreasing the cooking losses of meat sample, which gives the low intensity. According to the pervious data, the best ribs sample has high intensity. While, the hind shank was the lowest.

Table (1): Effect of physical characteristics on color properties of cut types of cow meat.

\begin{tabular}{|c|c|c|c|c|c|c|}
\hline \multirow[b]{2}{*}{$\begin{array}{l}\text { Meat cut } \\
\text { types }\end{array}$} & \multicolumn{3}{|c|}{ Color properties } & \multicolumn{3}{|c|}{ Physical properties } \\
\hline & $\begin{array}{c}\text { Intensity, } \\
\text { value }\end{array}$ & $\begin{array}{c}\text { Saturation, } \\
\text { value }\end{array}$ & $\begin{array}{c}\text { Hue } \\
\text { degree }\end{array}$ & $\begin{array}{c}\text { Shear } \\
\text { force, } \mathrm{N} \text {. }\end{array}$ & $\begin{array}{l}\text { Cooking } \\
\text { Loss, } \%\end{array}$ & $\begin{array}{c}\text { Water } \\
\text { holding } \\
\text { capacity,\% }\end{array}$ \\
\hline Best ribs & 37.91 & 19.6 & 70.8 & 4.82 & 51.88 & 26.18 \\
\hline Shoulder & 37.02 & 18.16 & 72.14 & 5.26 & 49.65 & 29.07 \\
\hline Round & 36.32 & 16.93 & 76.3 & 6.25 & 46.44 & 31.43 \\
\hline Hind shank & 35.62 & 14.19 & 79.52 & 9.31 & 43.66 & 37.7 \\
\hline
\end{tabular}

Fig.(4) reported that the effect of shear force, cooking loss, and water holding capacity percentage on the saturation as color properties of meat cut types of cow it noticed that the saturation values were decreased from19.6, 18.16, 16.93 and 14.19 for best ribs, shoulder, round and hind shank, respectively. Increases the shear force from 4.82, 5.20, 6.25 and $9.31 \mathrm{~N}$, and the water holding capacity from 26.18, 29.07, 31.43 and $37.7 \%$ while, the cooking losses percentage were decreased from 51.88, $49.65,46.44$, and $43.66 \%$, for best ribs, shoulder, round and hind shank, respectively. From previous data, by increasing of the shear force and the water holding capacity and decreasing the cooking losses of meat sample, which led to decreasing the saturation values. So, the best ribs meat sample was lighter than shoulder round and hind shank. While, the hind shank was the darker. 


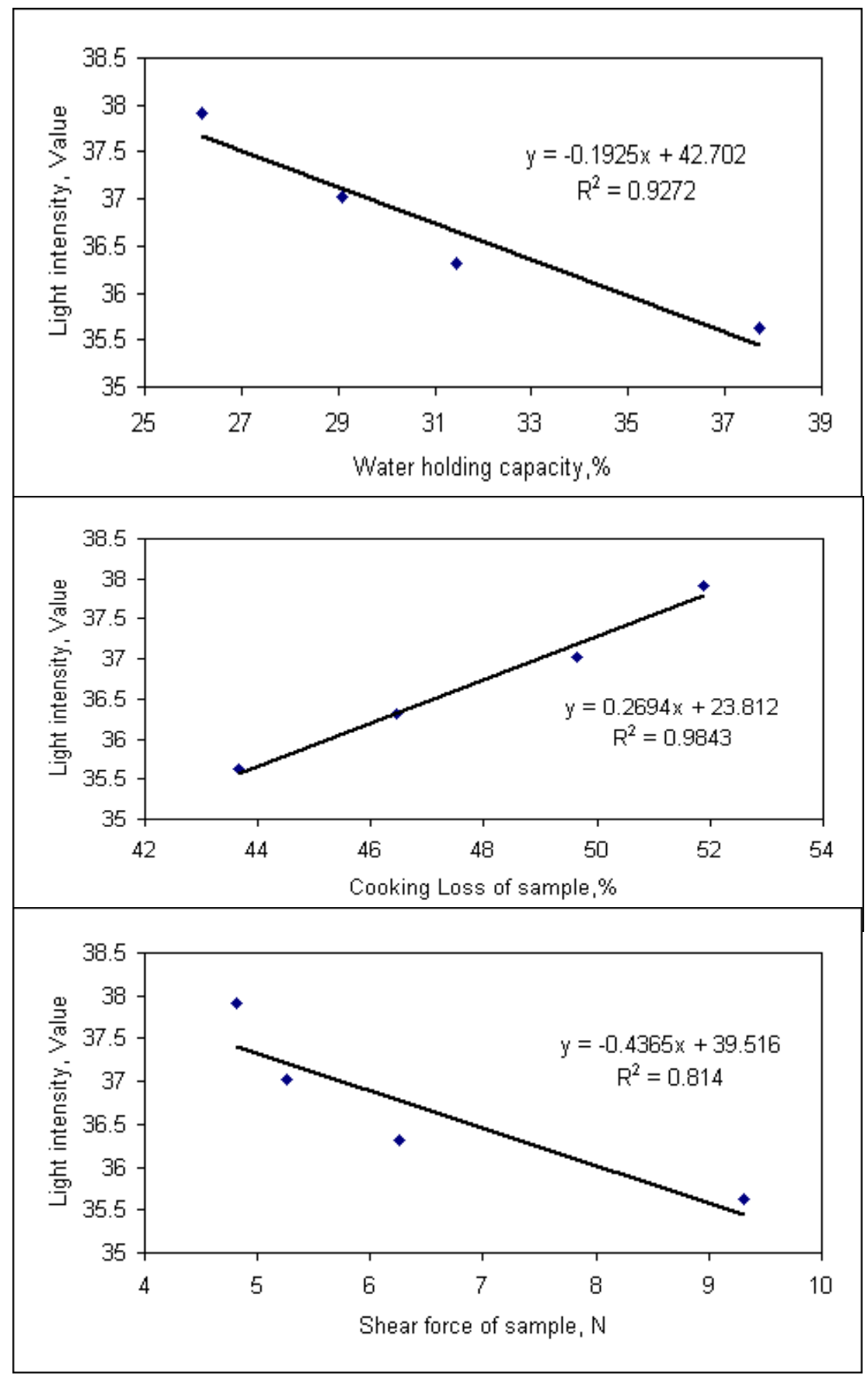

Fig. (3): Effect of water holding capacity, cooking loss percentages and shear force on light intensity of meat color. 


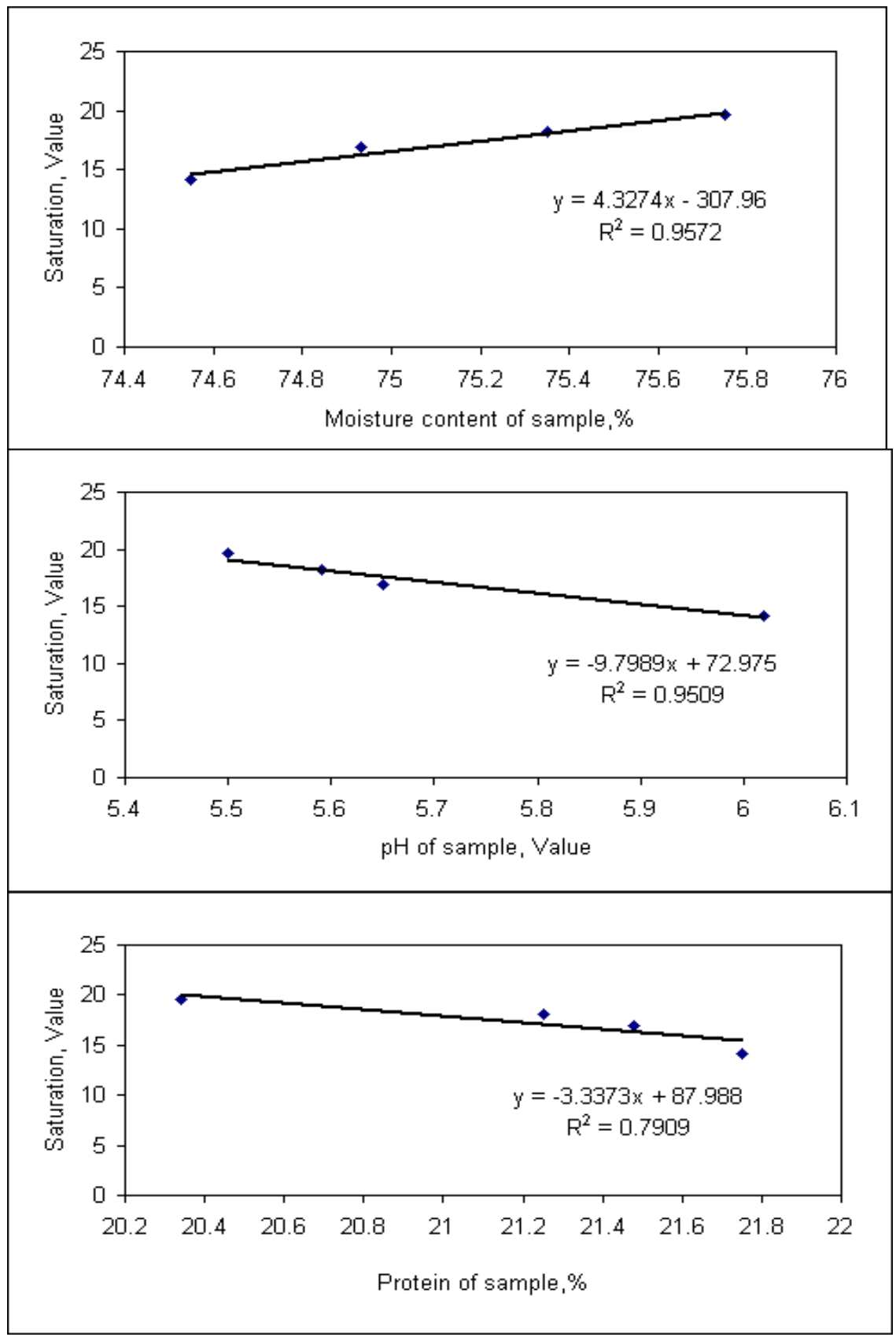

Fig. (4): Effect of protein, moisture content percentages and $\mathrm{pH}$ values on saturation values of meat color. 
Fig. (5) shows the effect of shear force, cooking loss, and water holding capacity percentage on the on hue degree as color properties. It noticed that the hue degree values were increased from70.8, 72.14, 76.3 and 79.52 degree for best ribs, shoulder, round and hind shank, respectively. Increases the shear force was increased from 4.82, 5.20, 6.25 and $9.31 \mathrm{~N}$, the water holding capacity was increased from 26.18, 29.07, 31.43 and $37.7 \%$ while, the cooking losses percentage were decreased from 51.88, $49.65,46.44$, and $43.66 \%$, for best ribs, shoulder, round and hind shank, respectively. Therefore, by increasing of the shear force and the water holding capacity and decreasing the cooking losses of meat sample that is led to increasing the hue degree of meat samples. So, the best ribs meat sample was red color degree different that shoulder and round, and hind shank. While, the hind shank was red color degree.

\section{-Effect of chemical properties on color properties of meat cut types of cow.}

The effect of the chemical properties on color properties of meat cut types of cow was discussed as follows.

Table (2): Effect of chemical characterizations on color properties of meat cut types of cow.

\begin{tabular}{|c|c|c|c|c|c|c|c|c|}
\hline \multirow{2}{*}{$\begin{array}{c}\text { Meat cut } \\
\text { types }\end{array}$} & \multicolumn{8}{|c|}{ Chemical properties for meat cut types of cow } \\
\hline & Ash,\% & \multicolumn{2}{|c|}{$\begin{array}{l}\text { Collagen, } \\
\%\end{array}$} & $\begin{array}{l}\text { Fat, } \\
\%\end{array}$ & \multicolumn{2}{|c|}{ Protein, $\%$} & $\begin{array}{l}\mathrm{PH}, \\
\text { value }\end{array}$ & $\begin{array}{l}\text { Moisture } \\
\text { content,\% }\end{array}$ \\
\hline Best ribs & 1.28 & \multicolumn{2}{|c|}{0.93} & 1.67 & \multicolumn{2}{|c|}{20.34} & 5.5 & 75.75 \\
\hline Shoulder & 1.25 & \multicolumn{2}{|c|}{1.39} & 1.55 & \multicolumn{2}{|c|}{21.25} & 5.59 & 75.35 \\
\hline Round & 1.19 & \multicolumn{2}{|c|}{1.52} & 1.33 & \multicolumn{2}{|c|}{21.48} & 5.65 & 74.93 \\
\hline \multirow[t]{3}{*}{ Hind shank } & 1.06 & & & 0.82 & & & 6.02 & 74.55 \\
\hline & \multicolumn{8}{|c|}{ Color properties for meat cut types of cow } \\
\hline & \multicolumn{2}{|c|}{ Intensity, value } & \multicolumn{3}{|c|}{ Saturation, value } & \multicolumn{3}{|c|}{ Hue degree } \\
\hline Best ribs & \multicolumn{2}{|c|}{37.91} & \multicolumn{3}{|c|}{19.6} & \multicolumn{3}{|c|}{70.8} \\
\hline Shoulder & \multicolumn{2}{|c|}{37.02} & \multicolumn{3}{|c|}{18.16} & & \multicolumn{2}{|c|}{72.14} \\
\hline Round & \multicolumn{2}{|c|}{36.32} & \multicolumn{3}{|c|}{16.93} & & \multicolumn{2}{|c|}{76.3} \\
\hline Hind shank & \multicolumn{2}{|c|}{35.62} & \multicolumn{3}{|c|}{14.19} & & \multicolumn{2}{|c|}{79.52} \\
\hline
\end{tabular}




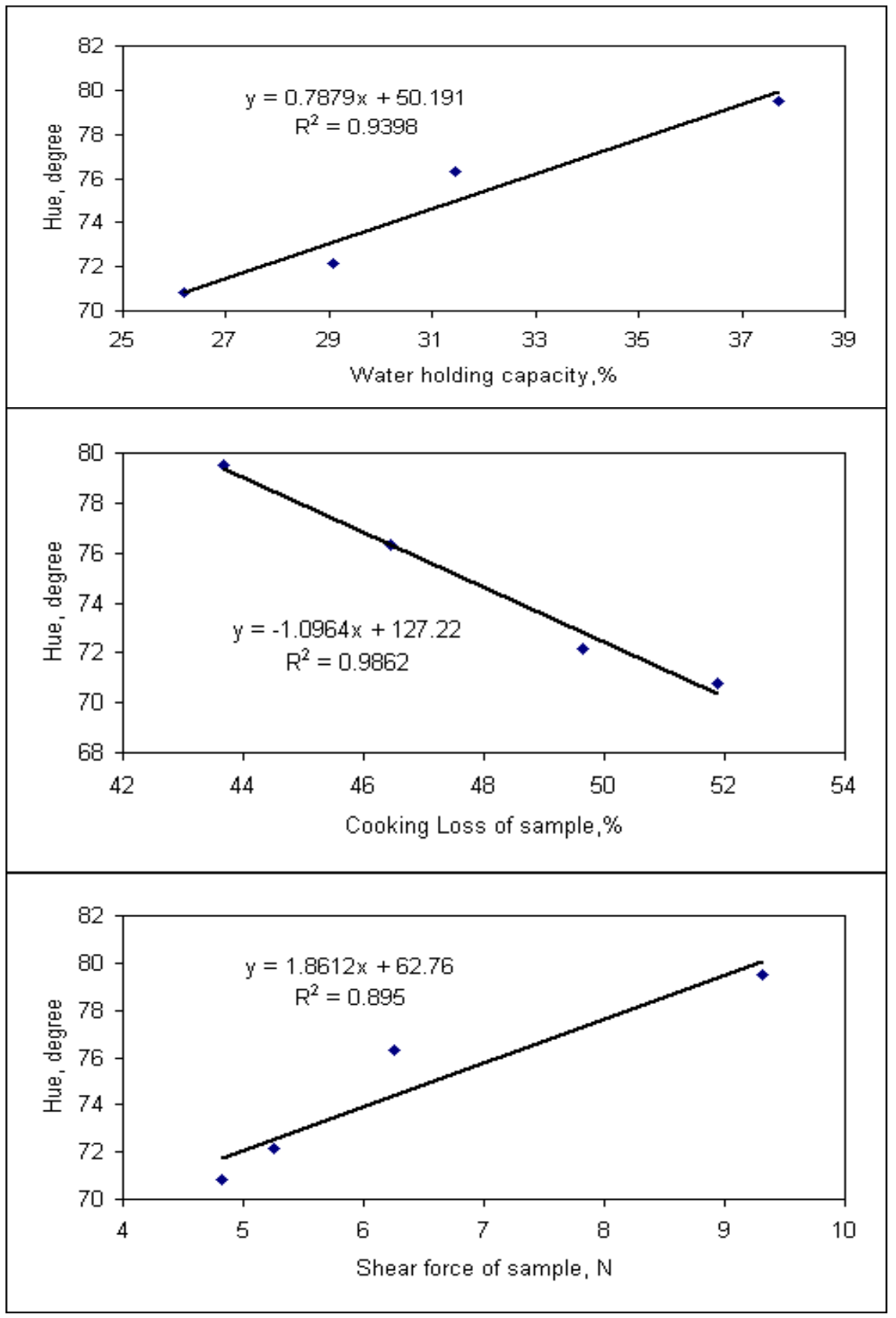

Fig. (5): Effect of protein, moisture content percentages and $\mathrm{pH}$ values on hue degree of meat color. 
Table (2) and Fig (6) showed that the effect of chemical properties such as the protein and the moisture content percentage and $\mathrm{pH}$ values on color properties such as the intensity values for meat cut types of cow. It noticed that by decreasing the moisture content percentage from 75.75, $75.35,74.93,74.55 \%$, while increases the protein percentage from 20.34, $21.25,21.48$ and $21.75 \%$, and the $\mathrm{pH}$ values from 5.5, 5.59, 5.65 and 6.02 values. That increasing led to the intensity values were decreased from 37.91, 37.02, 36.32 and 35.62 for best ribs, shoulder, round and hind shank, respectively. That is mean by increasing moisture content of meat sample, that gives the high intensity. According to the pervious data, the best ribs sample was high intensity while, the hind shank was the lowest.

Fig. (7) illustrated that the effect of chemical properties such as the fat, collagen, and ash percentage on color properties such as the intensity values for meat cut types of cow. It showed that decreases the fat percentage from $1.67,1.55,1.33$ and $0.82 \%$, and ash percentage from $1.28,1.25,1.19$, and $1.06 \%$ while increases collagen percentage from $0.93,1.39,1.52$ and $1.77 \%$, lead to the intensity were decreased from $37.91,37.02,36.32$ and 35.62 for best ribs, shoulder, round and hind shank, respectively. That is mean by decreasing fat percentage of meat sample, that gives the high intensity. According to the pervious data, the best ribs sample has high intensity. While, the hind shank was the lowest.

Fig. (8) shows the effect of chemical properties such as the protein and the moisture content percentage and $\mathrm{pH}$ values on color properties such as the saturation for meat cut types of cow. it cleared that the saturation values were decreased from 19.6, 18.16, 16.93 and 14.19 values according to this reduction, the moisture content percentage was decreased from $75.75,75.35,74.93,74.55 \%$ while increases the protein percentage from $20.34,21.25,21.48$ and $21.75 \%$ and the $\mathrm{pH}$ values from 5.5, 5.59, 5.65 and 6.02 for best ribs, shoulder, round and hind shank, respectively. Therefore, by decreasing the moisture content led to decreasing the saturation values. So, the best ribs meat sample was lighter than shoulder round and hind shank. While the hind shank was the darker. 


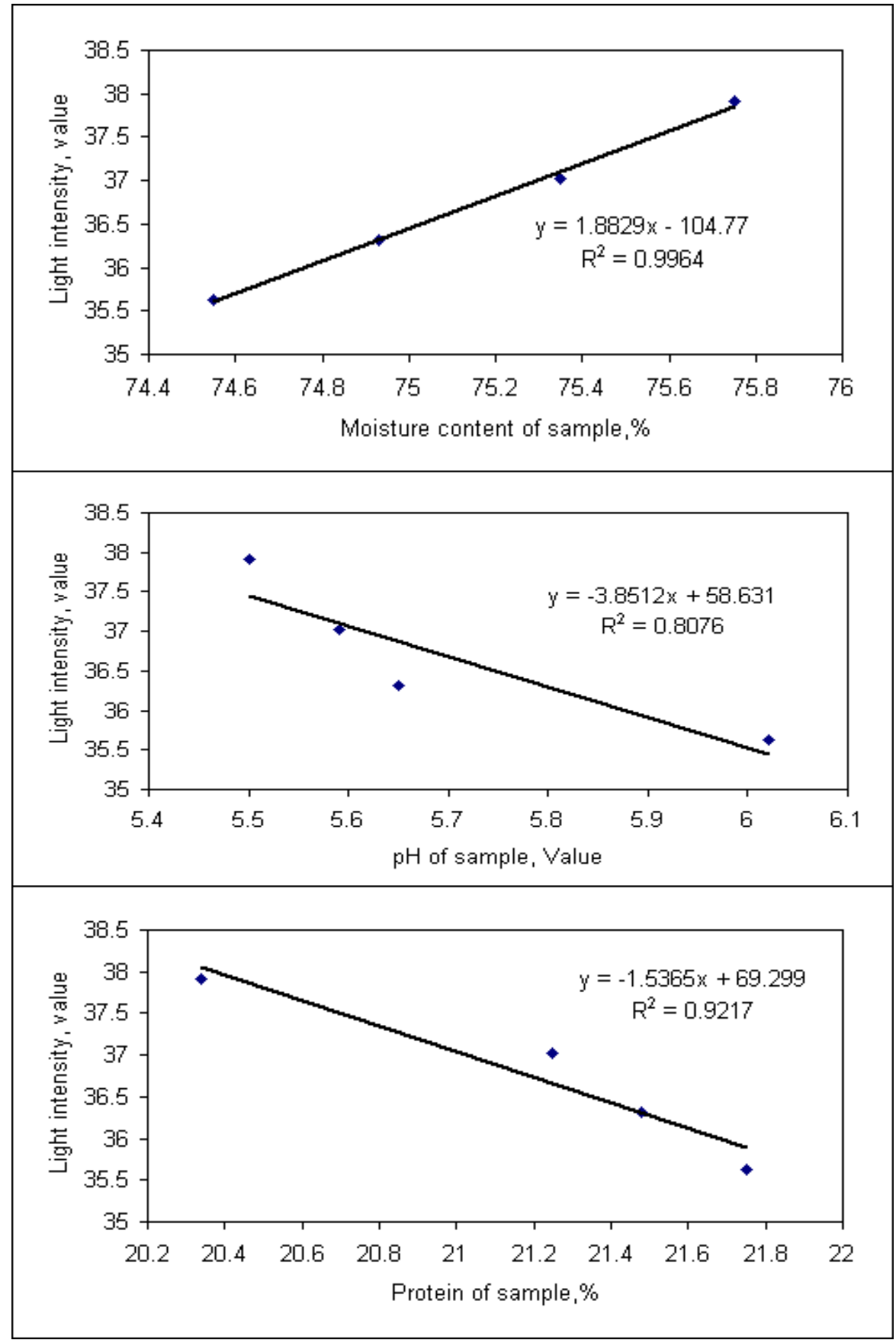

Fig. (6): Effect of protein, moisture content percentages and $\mathrm{pH}$ values on light intensity values of meat color. 


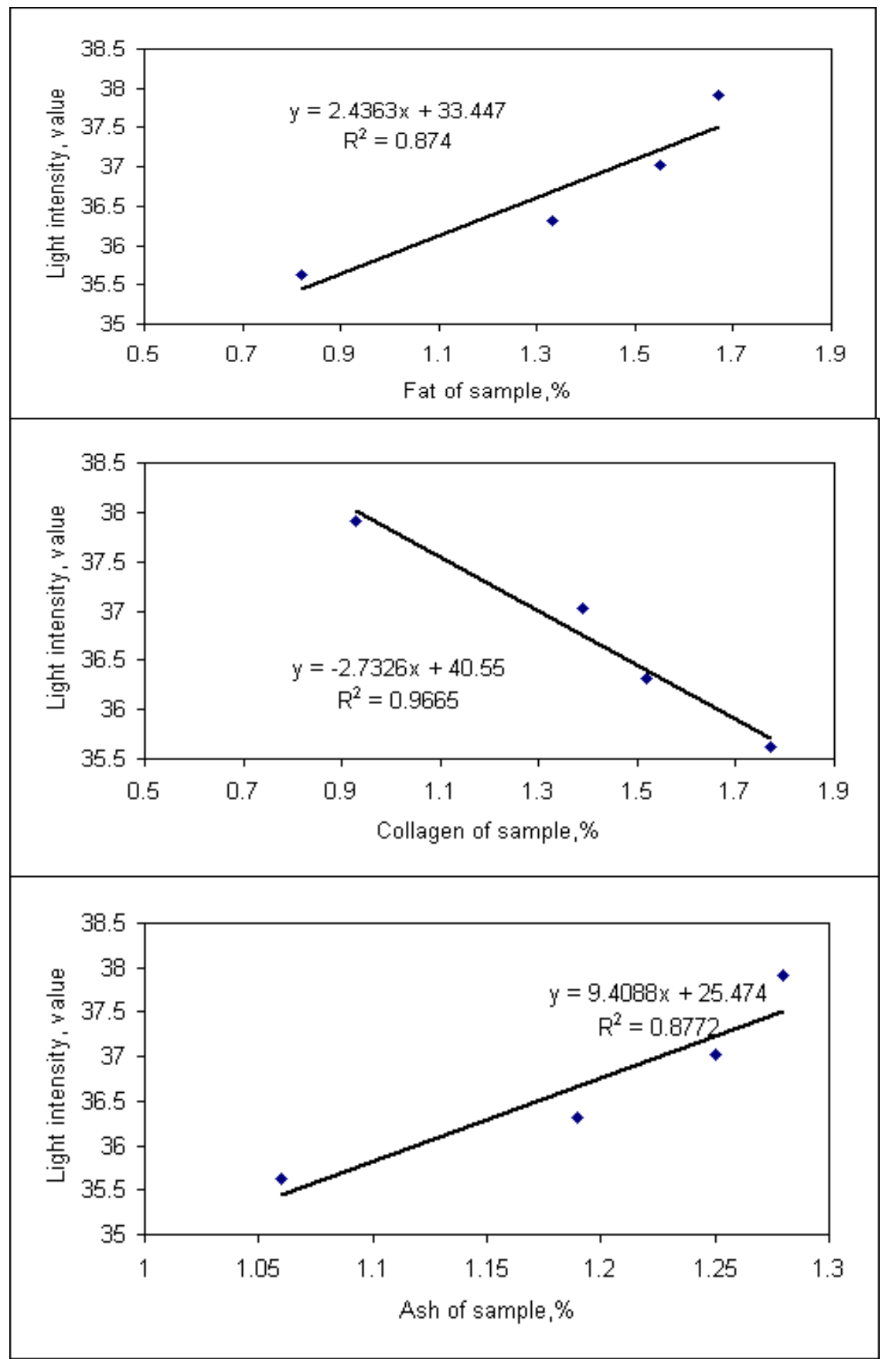

Fig. (7): Effect of fat, collagen and ash percentages on light intensity values meat color. 


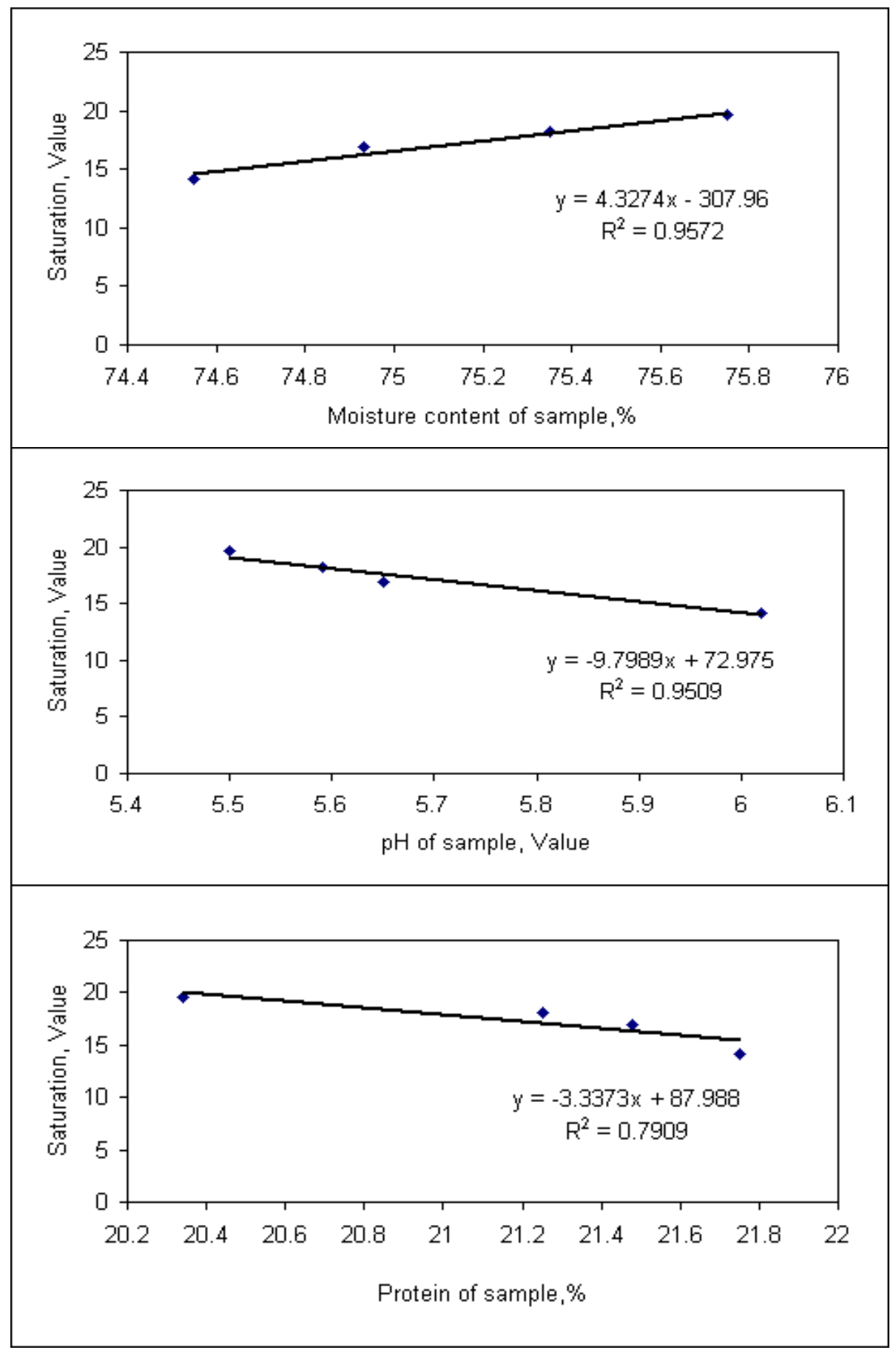

Fig. (8): Effect of protein, moisture content percentages and $\mathrm{pH}$ values on saturation values of meat color. 
Fig.(9) clears that the effect of chemical properties such as the fat, collagen, and ash percentage on color properties such as saturation for meat cut types of cow. It showed that the saturation values were decreased from19.6, 18.16, 16.93 and 14.19 value, according to this reduction, the fat percentage was decreased from 1.67, 1.55, 1.33 and $0.82 \%$, and ash percentage from $1.28,1.25,1.19$, and $1.06 \%$. While, increases collagen percentage from $0.93,1.39,1.52$ and $1.77 \%$ for best ribs, shoulder, round and hind shank, respectively. From previous data, by decreasing the fat percentage led to decreasing the saturation values. So, the best ribs meat sample was lighter than shoulder, round and hind shank. While the hind shank was the darker one.

Fig. (10) shows the effect of chemical properties such as the protein and the moisture content percentage and $\mathrm{pH}$ values on color properties such as Hue degree. It noticed that the hue degree values were increased from $70.8,72.14,76.3$ and 79.52 degree these increases led to decrease the moisture content percentage from 75.75, 75.35, 74.93, 74.55\%. While, increases the protein percentage from 20.34, 21.25, 21.48 and $21.75 \%$, the $\mathrm{pH}$ values from 5.5, 5.59, 5.65 and 6.02 for best ribs, shoulder, round and hind shank, respectively. Therefore, by increasing the $\mathrm{pH}$ values led to increasing the hue degree of meat samples. So, the best ribs meat sample was red color degree different that shoulder and round, and hind shank. While the hind shank was red color degree.

Fig.(11) referred to the effect of chemical properties such as the fat, collagen, and ash percentage on color properties such as hue degree for meat cut types of cow. It showed that the hue degree values were increased from 70.8, 72.14, 76.3 and 79.52 degree this reduction led to decreases the fat percentage from $1.67,1.55,1.33$ and $0.82 \%$, and ash percentage from $1.28,1.25,1.19$, and $1.06 \%$. While, collagen percentage was increased from $.93,1.39,1.52$ and $1.77 \%$ for best ribs, shoulder, round and hind shank, respectively. Therefore, by decreasing the fat percentage led to increasing the hue degree of meat samples. So, the best ribs meat sample was red color degree different that shoulder and round, and hind shank. While the hind shank was more different red color degree. 


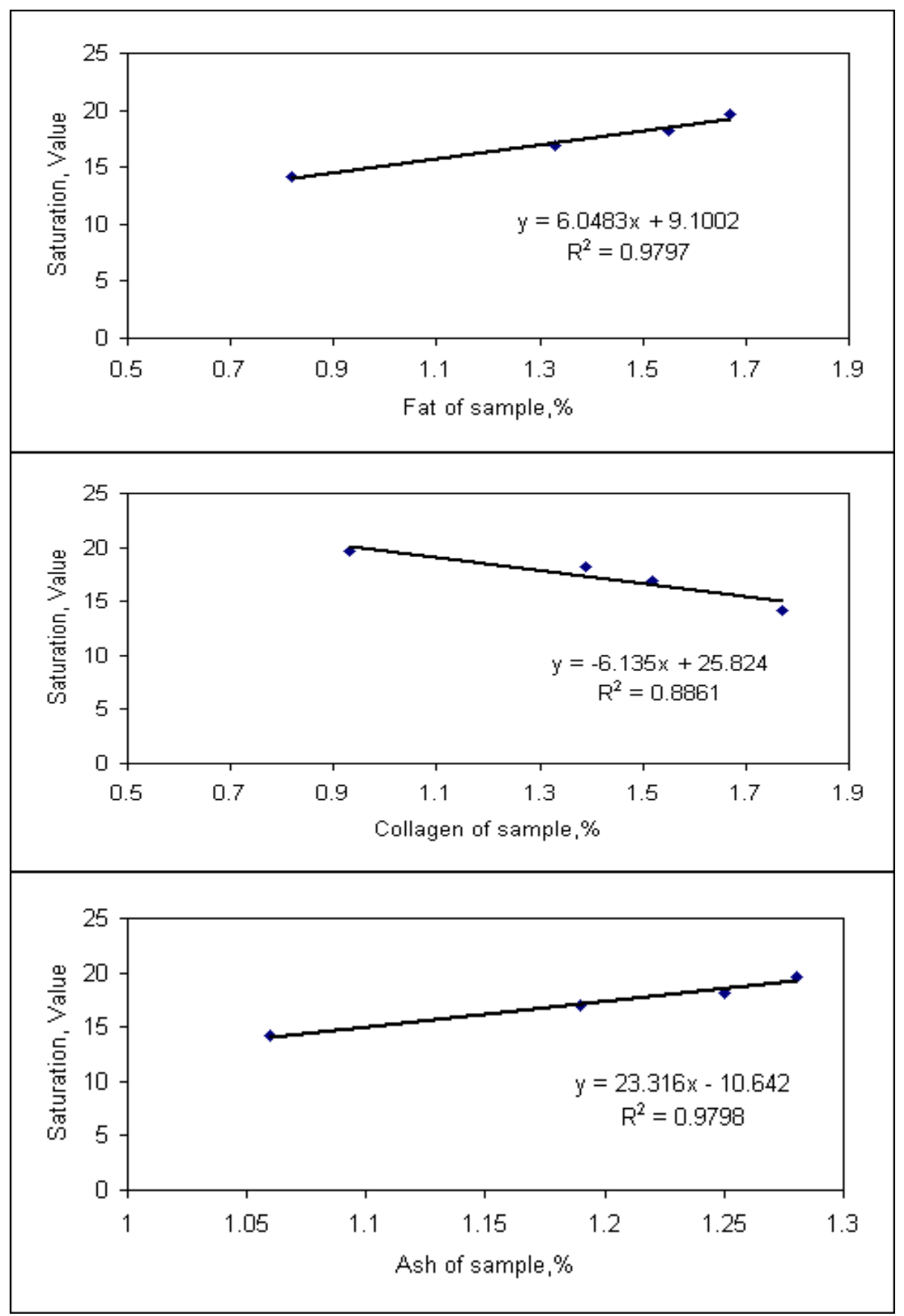

Fig. (9): Effect of fat, collagen and ash percentages on saturation values of meat color. 


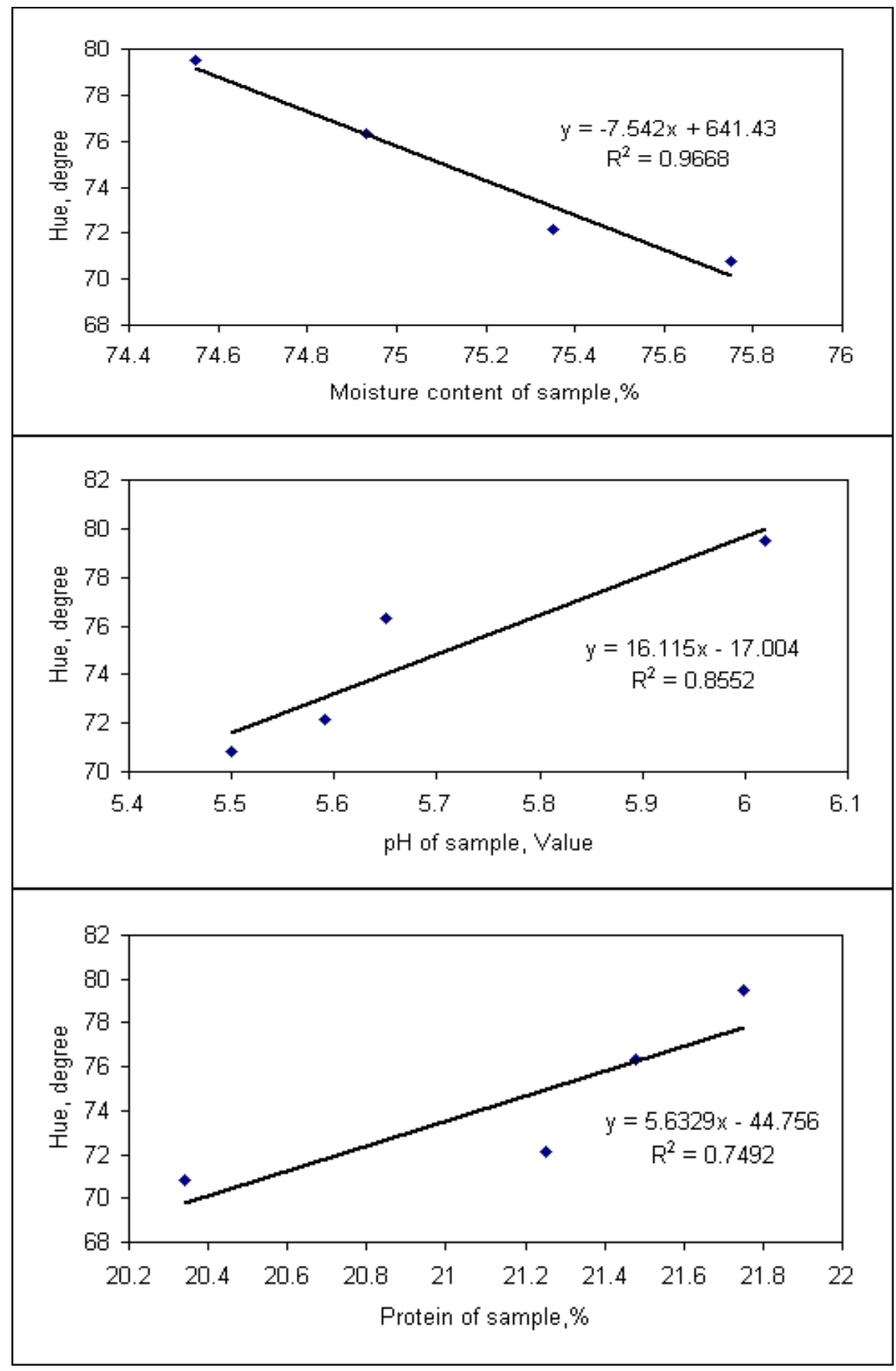

Fig. (10): Effect of protein, moisture content percentages and $\mathrm{pH}$ values on hue degree of meat color. 


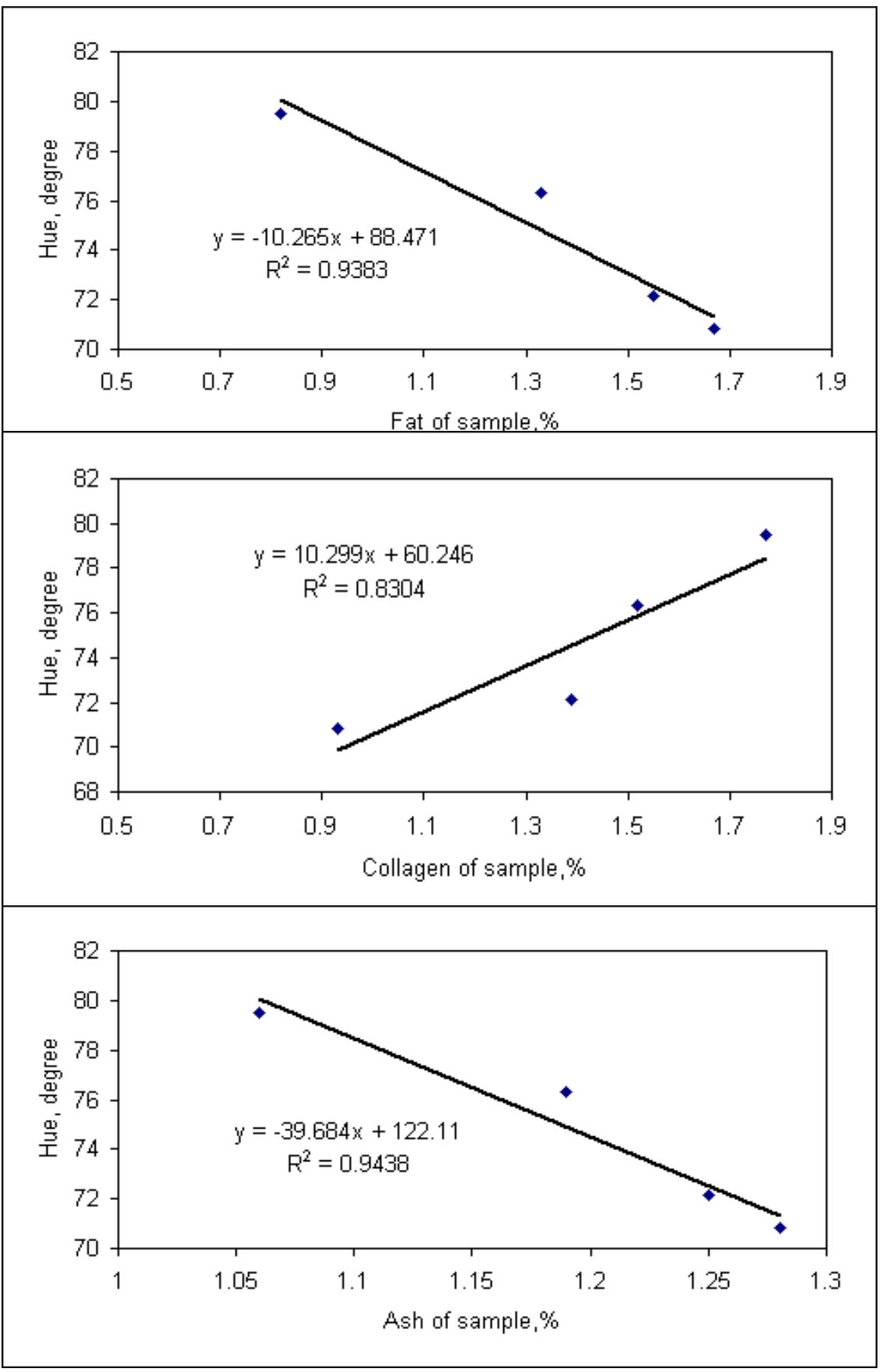

Fig. (11): Effect of ash, collagen and fat percentages on hue degree of meat color. 


\section{CONCLOSION}

The obtained results were as following: (a) By increasing of the shear force and the water holding capacity and decreasing the cooking losses of meat sample, these result led to the lowering of intensity and saturation values. While increases of the hue degree for best ribs, shoulder, round and hind shank of meat cut type of cow., (b) By decreasing the moisture content, fat, and ash percentages and increasing the protein, collagen percents and $\mathrm{pH}$ values led to decrease the intensity and saturation values of meat cut while hue degree was increased for best ribs, shoulder, round and hind shank, respectively., (c) The best ribs sample has high intensity of light, lighter of saturation and red color degree than shoulder, round and hind shank samples. While, the hind shank sample was the lowest of intensity, darker and more red color degree., and (d) Image processing as a machine vision technique can be used for evaluating quality of meat cut types.

\section{REFFERENCES}

Abril, M.; M.M. Campo; A. Onenç; C. Sanudo; P. Alberti and A. I. Negueruela (2001). Beef color evaluation as a function of ultimate $\mathrm{pH}$. Meat Science, 58, 69-78.

American Meat Science Association (1991).Guidelines for Meat Color Evaluation. Published by the American Meat Science Association. $44: 5-12$.

Balkeninues, M.N.; S. S. Kadam and D. Drost (2003). Evaluation of some food color by image analysis. Journal of Food Engineering, 54, 233-238.

Chance Brooks (2007). Product Enhancement Beef Packaging Cattlemen's Beef Board. National cattlemen's association, Pages: $1-5$.

Chandraratne, M. R. ; S. Samarasinghe; D. Kulasiri and R. Bickerstaffe (2006). Prediction of lamb tenderness using image surface texture features. Journal of Food Engineering, 77, 492-499. 
Dave McKenna Meat Science Section (2007). The Color of Meat. Meat Science Section . Department of Animal Science Texas A\&M University pages 1-2.

Denoyelle, C. and F. Berny (1999). Objective measurement of veal color for classification purposes. Meat Sci. 53:203-209.

Gunasekaran, S. (2001). Non-destructive food evaluation techniques to analyze properties and quality. Food Sci. and Tech. (vol.105) New York: Marcel Decker.

Hal Good, (2007). Solving Color Measurement Challenges of the Food Industry Hunter Lab., Reston, VA Pp: 1-4.

Hatem, I.; J. Tan and D. E. Gerrard (2003). Determination of animal skeletal maturity by image processing. Meat Science, 65:999-1004.

James, R. (2007). Color Changes in Cooked Beef .University of Wisconsin-Madison Cattlemen's Beef Board. Pages: 1-5.

Kayaardi, S. and V. Gök (2003). Effect of replacing beef fat with olive oil on quality characteristics Of Turkish soudjouk (sucuk). Meat Science, 66:249-257.

Li, J.; j. Tan and p. Shatadal (2001). Classification of tough and tender beef by image texture analysis. Journal of Meat Science, 57, 341346.

Lu, J.; J. Tan; P. Shatadal and D. E. Gerrard (2000). Evaluation of pork color by using computer vision. Meat Science, 56: 57-60.

Sun, D. W. (2000). Inspecting pizza topping percentage and distribution by a computer vision method. Journal of Food Engineering, 44, 245-249. 


\section{الملخص العزبي}

\section{طريقة الروئية الآلية لتقييم جودة اللحم البقرى}

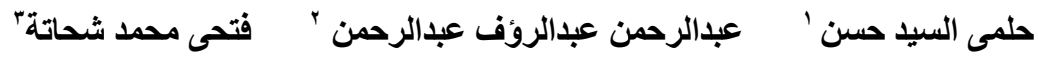

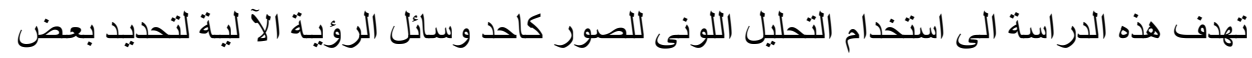

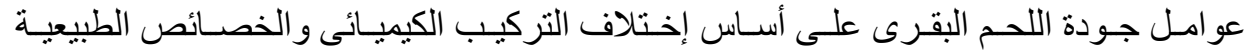

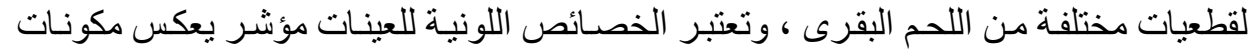

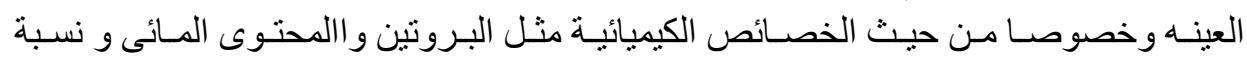

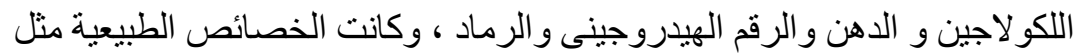

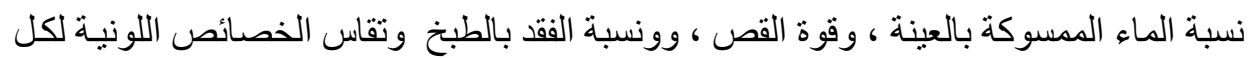
قطعية على اساس كمية الضوئية بالعينة ، وقيمة تشبع اللون ، ودرجة اللونة اللون للعينة.

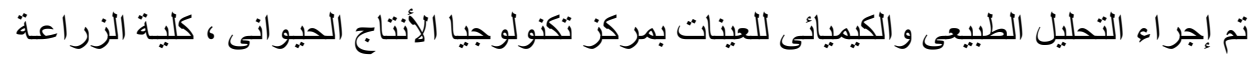

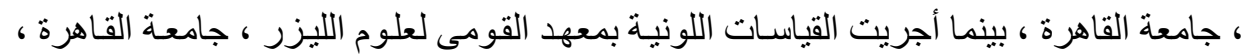

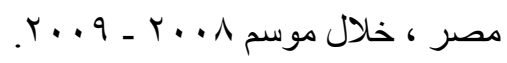

أوضحت النتائج المتحصل عليها الأتى :

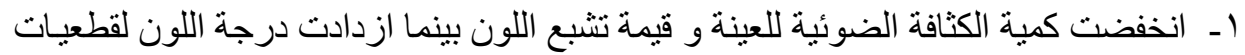

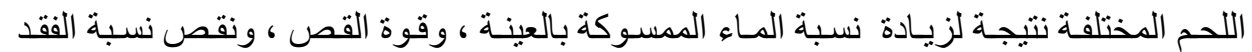

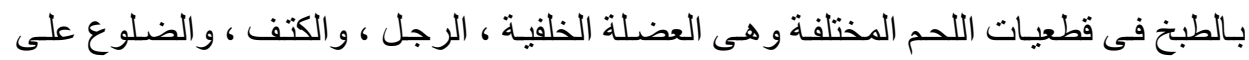
الترنيب. بـ بزيـادة كل من المحتوى المسائى ، ونسبة الدهن ونسبة الرمـاد و انخفاض كل من قيم الرقم

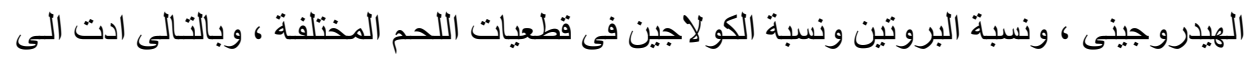

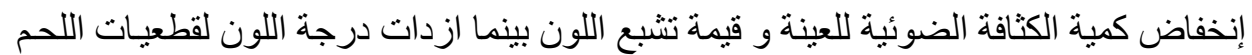

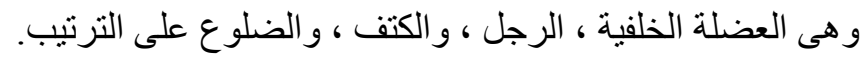

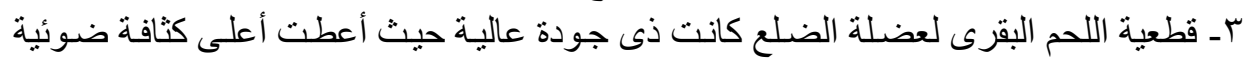

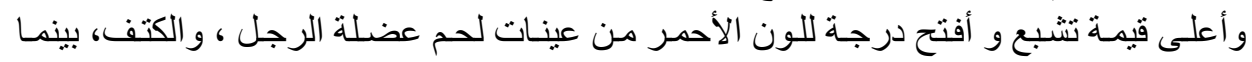

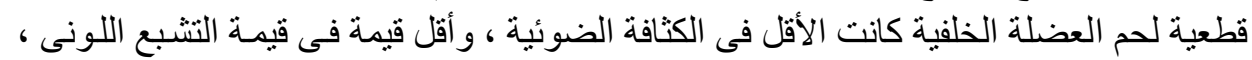
و أغمق فى درجة اللون الأحمر. عـ يمكن استخدام التحليل اللونى للصور ( للعينات ) كأحد وسائل تقييم جودة للحوم على اسـاس الاس التركيب الطبيعى و الكيميائى للعينات.

ا ـ أستاذ مساعد تطبيقات الليزر فى الهندسة الزراعة ـ المعهد القومى لعلوم الليـزر - جامعـة القاهرة - مصر.

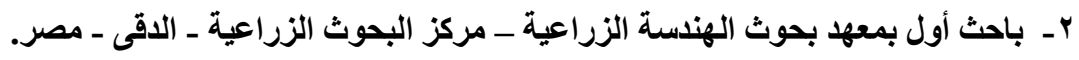

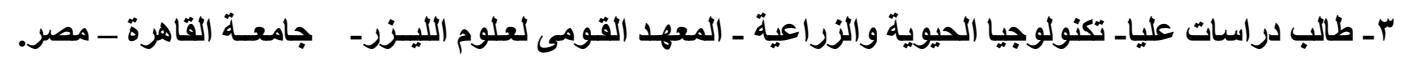

